\title{
Työ muuttuu, muuttuuko työntekijä?
}

Ari Väänänen \& Jussi Turtiainen (toim.). Suomalainen työntekijyys 1945-2013.

Vastapaino 2014. 300 s. ISBN 978-951-768-444-6

TYÖELÄMÄSTÄ JA TYÖN kehityksestä kertovia teoksia ilmestyy vuosittain suurin määrin, mutta harvemmin ilmestyy tutkimuksia työntekijyyden muutoksista.

Teoksen tarkoitus on selvittää, kuinka suomalaisen työelämän suuri kertomus, kansainvälisesti ennätysmäisen raju rakennemuutos pelloilta ja metsistä teollisuuteen ja sitten palvelu- ja asiantuntijatöihin, vaikutti työntekijää koskeviin odotuksiin.

Työntekijäkuvat ovat kulttuurisia ideaaleja ja merkitystihentymiä, mutta kirjan toimittajat uskovat niiden olevan vastavuoroisessa yhteydessä palkkatyön ja työpaikkojen todellisuuteen ja heijastelevan laajemminkin kulttuuris-sosiaalisia muutoksia. Kirjan otetta he kutsuvat yhteiskuntatieteellisesti suuntautuneeksi työelämän historian tutkimukseksi.

\section{NEUVOTTELUTAIDOISTA KOVAA VALUUTTAA}

Kirjoittajia kiinnostaa ilmaantumisen historia eli ilmiöiden nousut ja läpimurrot. Kultturisissa malleissa eli tässä tapauksessa työntekijäideaaleissa voidaan eri aikoina havaita niin orastavia, vallitsevia kuin jäänteenomaisia piirteitä.

Toimittajien mukaan ensimmäiset merkit suomalaisen työntekijyyden laajemmasta muutoksesta näkyivät 1950-60-lukujen taitteessa. Työpaikkailmoittelua ja johtamisoppeja tutkittaessa kävi ilmi, että työntekijöiden psyykkisiin ja sosiaalisiin ominaisuuksiin alettiin kiinnittää huomiota. Enää ei riittänyt, että työntekijä on "täysin ammattitaitoinen ja raitis" (HS:n työpaikkailmoitus 6.2.1949).

Työpaikoille tuli lisää koulutettuja työnjohtajia ja esimiehiä. Samalla laajenivat organisaatioiden talous-, markkinointi- ja henkilöstöosastot. 1970-luvulle tultaessa työntekijän sosiaaliset taidot, kuten neuvottelutaidot, alkoivat olla kovaa valuuttaa.

\section{JOTAIN ON TAPAHTUMASSA}

Opettajaihanne alkoi muuttua kurinpitäjästä ja moraalikoodien varmistajasta nykyiseksi tunnevalmentajaksi. Kasvatusopit vaihtuivat 1960-luvulla demokraattiseen suuntaan. Murrosta ja rajoilla oloa kuvaa opettaja ja Kansakoulunopettajain liiton puheenjohtaja Lauri Järvi (Opettajain lehti 47/1959) näin:

"Olemme ymmällä, sillä jotain sellaista on tapahtumassa nuorisomaailmassa, jota emme käsitä. [-] Koditkin valittavat voimattomuuttaan [--]".

Mieleen tulee Bob Dylanin laulu muutamaa vuotta myöhemmin: "Because something is happening here / But you don't know what it is / Do you, Mister Jones?"
Työsuojelulainsäädännössä ja työelämäkeskustelussa nousi esiin työntekijän subjektiivinen kokemusmaailma, kuten työssä viihtyminen ja tyytyväisyys sekä yksilöllinen työmotivaatio.

Työelämän humanisointi- ja reformihenki liittyivät tuolloin eksoottiselta vaikuttavaan laajaan yhteiskunnalliseen hyvinvoinnin projektiin ja hyvinvointivaltion instituutioiden vahvistamiseen. Katsottiin, että sekä työtä että lisääntyvää vapaa-aikaa rikastamalla voidaan aktivoida kansalaisia ja estää vieraantumista. Terveelliset työolot ja vapaa-ajan elintavat nostettiin keskusteluun. Työelämän demokratisoinnistakin puhuttiin, vaikka asiassa ei edetty samalla tavoin kuin muissa Pohjoismaissa. Talouden kasvu, valtiokapitalismi ja työmarkkinoiden sopimusinstituutioiden kehitys tukivat toisiaan.

\section{PREKARISAATIOTA EI ENNUSTETTU}

Osin kirjan keskustelun ulkopuolelta sallittaneen muistikuva 1970-1980-luvun taitteen työprosessikeskusteluista. Tällöin oli jo monin tavoin nähtävissä tietotekniikan ja muiden mullistusten tuoma töiden syvällinen muutos.

Keskusteluissa esitettiin kolme kilpailevaa teesiä. Rekvaliffkaatioteesi heijasteli edistysuskoa 
ja ennusti osaamisvaatimusten ja mielekkyyden yleistä lisääntymistä. Dekvalifikaatioteesin mukaan kehitys olisi juuri päinvastainen. Polarisaatioteesi ennakoi töiden voimakasta jakautumista statuksen ja mielekkyyden suhteen.

Työelämän kehitys on sittemmin ollut niin paradoksaalista, että varmaankin kaikkien kolmen teesin tuolloiset kannattajat voisivat nyt sanoa olleensa kaukonäköisiä ja osuneensa oikeaan. Sen sijaan nykyisen globalisaation seurauksia työmarkkinoille, hyvinvointivaltion muuttamista kilpailuvaltioksi tai kaikkiin työntekijäryhmiin ulottuvaa prekarisoitumista ei kai kukaan tuolloin, palkansaajan kulta-ajan lopulla, osannut ennakoida.

\section{SUBJEKTIN NOUSU}

Vuodet 1979-1992 kirjan toimittajat nimeävät subjektiviteetin nousun kaudeksi. Suuret ikäluokat olivat 1980-luvulla vasta kolmekymppisiä. Koulutus- ja kulutustaso nousivat ja toimihenkilöistyminen kiihtyi. Työntekijöiden tukemiseen (muun muassa työterveys) riitti aiempaa enemmän resursseja.

Työntekijöitä ja organisaatiota katsottiin entistä tarkemmin erilaisten johtamisoppien ja psykologian silmälasein. Työntekijöiltä alettiin vaatia joustavuutta ja organisaatioilta ketteryyttä.

Kun reformien kaudella ongelmat liittyivät usein kollektiivisiin vastakkainasetteluihin, kehitys kulki 1980-luvulla kohti työpaikkojen ilmapiirin, psyykkisten työolojen ja esimiestyön kehittä- mistä. Ihanteeksi nostettiin feminiinisyyteen liitettyjä tunne- ja organisointitaitoja, mutta samalla työnantajat arvostivat maskuliinisina pidettyjä yksilöllisyyttä, kunnianhimoa ja kilpailullisuutta.

\section{RIITTÄMÄTTÖMYYDEN TUNNETTA}

Vuodesta 1993 alkanut jakso saa kirjassa nimekseen "tiivistymisen kausi". Työntekijän standardi oli korkeakoulutettu erityisosaaja, ellei peräti huippuosaaja, ja samalla pidäkkeetön innovoija. 1990-luvun lamanjälkeisissä oloissa kaivattiin kasvua muun muassa tunne-elämysten tuottamisen avulla.

Työntekijän uusiksi määreiksi nousivat "tunneälytaidot" ja äärimmäinen sitoutuneisuus, mutta samalla sitoutumisen vastakohta, valmius muutoksiin ja saaliseläimen valppaus. Kun työntekijä nähtiin aiemmin vajavaisena ja johdon valistavien toimenpiteiden kohteena, nykyaikaa lähestyttäessä vajavaisuuden leima säilyy, mutta kehittäjänä on nyt itseään johtava ja yksilöllistetty työntekijä itse.

Työn intensiivisyyden lisääntyminen ja monimutkaistuminen on voitu ainakin Britanniassa osoittaa laajan aineiston alulla. Samalla tuottaja ja tuote ovat tulleet vaarallisen lähelle toisiaan. Raija Julkusen teesin mukaan vailla kollektiivisuuden puskuria työ "tärähtää" suoraan tekijään. Persoonallistunut työ sulautuu tekijäänsä, kolonisoi ja "ylikuumentaa" minuuden. Furedin mukaan aiemmin poliittisin käsittein tulkitut työelämäkysymykset voidaan nyt tulkita yksilöterapian ja mielenterveyspuheen keinoin. Työn ja työelämän henkilökohtaistuminen, yksilöllistyminen ja epäpolitisoituminen luovat riittämättömyyden tunnetta, mielekkyyden katoamista ja vaikeasti määriteltävää pahoinvointia.

\section{TYÖELÄMÄN TUTKIMUS HÄMMENTÄÄ}

Työelämän tutkimus on pyrkinyt ratkomaan työelämän ongelmia. Erilaisia yksilöllisen selviytymisen strategioita on pyritty tunnistamaan 1970-luvulta alkaen. Käsitteitä ovat olleet coping, koherenssi ja minäpystyvyys.

1990-luvulla positiivinen psykologia nousi tukemaan yksilöllisiä voimavaroja käsitteinään muun muassa työn imu ja optimismi. 2000-luvun alussa yleistyneet yksilön psyykkistä kestävyyttä lisäävät kehittämishankkeet voidaan teoksen toimittajien mukaan nähdä pikemminkin osana ongelmaa kuin ratkaisuna.

Kun työelämän kaoottisuutta ei voi hallita, hallitaan sitä mitä voidaan, eli omaa itseä. Psykokulttuurin kritiikki kovenee, ja tätä keskustelua on teoksen loppuluvussa tiiviisti selostettu.

Kirjassa kiinnitetään aiheellisesti huomiota työelämän tutkimuksen ristiriitaisuuteen. Eri lähteiden tietystä ajanjaksosta antamissa kuvissa on vaikea tunnistaa yhtäläisyyksiä. Sotien jälkeiset työntekijäkuvat ovat olleet toisistaan irrallisia ja eritahtisia. 
Vanhojen työntekijäideaalien päälle asetetaan uusia, mutta vanhojen ideaalien jotkut puolet saattavat nousta esiin hieman muuntuneina. Tällöin vanhat asiat on voitu uudelleen myydä organisaatioille sopivasti tuunattuina. Jotkut johtamisoppien muodit puolestaan näyttävät vuorottelevan heiluriliikkeenä.

\section{PREKAARI MIELENTILA JÄÄ HUOMIOTTA}

Suomalaiset työntekijäideaalien muutokset ovat olleet lainaa suuresta maailmasta, mutta valitettavasti kirjassa ei laajemmin selvitetä kansainvälisten vaikutteiden kulkeutumisia meille, joskin joitain yksittäisiä väläyksiä tuodaan esiin.

Tosin kulkeutumisen jäljittäminen olisi varmaankin kasvattanut tämän teoksen tarkastelukulmaa liian laajaksi. Enemmän olisi toivonut keskustelua prekarisaatiosta ja pätkätyöläisten prekaarista mielentilasta sekä italialaisen operaismo-koulukunnan ajattelusta - jota tänä vuonna ilmestyvä Aikuiskasvatuksen vuosikirja tuo esiin.

Kirjoittajat ovat Työterveyslaitoksen tutkijoita, ja artikkeleissa kiinnitetään huomiota yleisten kehityskulkujen lisäksi työtervey- den ja työhyvinvoinnin näkökulmiin. Ulkopuolelle on puolestaan jouduttu jättämään työssä oppimisen, epävarmuuden, työelämävalmennuksen, yrittäjyyskasvatuksen ja ammatinvalinnan ilmiöt, joista varmaankin saisi runsaasti lisäaineistoa itsehallintavaatimusten ja yksilöllistymisen kuvauksiin.

Kirjan jäsennys on seuraava: Aluksi tarkastellaan työntekijyyden ja työntekijäideaalien historiaa (toimittajat), työpaikkailmoituksia (Pekka Varje), johtamisoppaita (Anna Kuokkanen), opettajien työnkuvaa (Erkko Anttila), metallialan maskuliinisuutta (Turtiainen), työsuojelua (Sirkku Kivistö ja toimittajat) sekä riskejä ja työterveyttä lehdistökeskustelussa (Väänänen ja Varje).

Päätösluku on oikeastaan kirjan pääluku, toimittajien monipuolinen katsaus työntekijyyden kehitykseen vuodesta 1945 nykypäiviin. Teosta voi ilman muuta suositella työelämän pitkistä kehityslinjoista kiinnostuneille.

Jussi Onnismaa

Dosentti,

Kehityspiikki Consulting Oy 